Marketing in Asia Group

\title{
Does the Board Gender Diversity Enhance Firm Performance?
}

\author{
Rita R. Pidani \\ Faculty of Business and Law, University of Newcastle, Singapore \\ Amir Mahmood \\ School of Business, Western Sydney University, Australia \\ Frank W. Agbola \\ Newcastle Business School, University of Newcastle, Australia
}

\begin{abstract}
Board gender diversity is a keenly debated topic in both management practice and academic discourse. This study examines the influence of board gender diversity on firm financial performance in four ASEAN countries. Adopting agency and resource dependence approaches, board gender diversity's interactions with three mediating organizational variables are evaluated against four organisational performance measures. Partially supporting agency theory and resource dependence theory, the results suggest that board gender diversity are only positively associated with sales to fixed asset ratio and sales per employee ratio. The BGD's effects at the organisational level are mediated distinctly by firm size, ownership structure, and industry nature respectively, and by the multivariate interaction among these variables. The results of this paper support the findings of other studies that found a partially significant link between the board gender diversity and the firm's performance. Decision-makers in society and politics, therefore, need to be aware of the empirical evidence indicating that stimulating organisational environment may need to be configured before the valuable outcomes of gender diversity can be achieved.
\end{abstract}

Keywords: Board Gender Diversity, Gender Diversity, Female Director, Firm Performance, ASEAN Countries 


\section{Introduction}

Achieving the efficiency frontier would probably be seen as the most important stage of economic development for most economies. From a macroeconomic perspective, this efficiency edge can only be achieved if an economy can use its available primary and secondary factors of production to the absolute limit. Entrepreneurs, as part of the secondary factors of production, possess distinctive attributes that often preclude their abilities to achieve their full potential. Critical factors such as entrepreneurs' psychological and personal traits and characteristics, and the external environment often negatively impact the capacity of this economic segment to participate and contribute to the production of goods and services, and by extension, to the economy as a whole.

Gender disparity in business ownership is one of the most common personal trait issues in more patriarchal societies. Due to the complex nature of the accompanying socio-economic factors of these settings, no significant headway towards gender equality is imminent. Whilst female labour force participation in some contexts has increased considerably, in that women have increasingly moved up the managerial ladder in domains traditionally controlled by men, research in gender diversity in management indicates that the proportion of women in board-level positions remains significantly under-represented (Hillman, Shropshire \& Canella, 2007; ILO, 2017 ). Although data from the International Labour Organisation (World Bank Group, 2017) indicate that female labour participation in many countries has risen steadily in recent decades, there is insufficient research on whether this increase is truly associated with the increasing numbers of women at board level and in upper management.

The female labour participation rate is, incontestably, a focal point that has a direct impact on the value of both developed and developing economies. A study by McKinsey Global Institute for instance, estimated that the ASEAN region could potentially raise its collective gross domestic product by 30 percent or 1.2 trillion dollars if proper schemes are taken to address the issues that inhibit women from achieving gender equality such as income, infrastructure, integration, and institutional gaps within society (The Asean Post, 2017), all of which are the emphasis of the AEC (ASEAN Economic Community) roadmap. A prior study by AEC in 2016 indicated that female labour force participation had improved, particularly in rapidly growing markets such as Singapore and the Philippines. In different niches such as Thailand and Laos, female workforce involvement has stayed largely unchanged since 1990. The typical upward tendency across ASEAN parallels other countries in Asia-Pacific (except China and Japan). A data survey by Ernst and Young in 2017 finds that women made up between 35 and 50 per cent of the work force in ASEAN countries, yet held only between 7.7 and 12.5 per cent of the board seats (Ernst and Young, 2017). In the popular press, the representation of women boards in corporate ASEAN is heavily discussed (e.g., Ramly, Chan, Mustapha \& Sapiei, 2015; Chotiyaputta \& Yoon, 2018) and institutional frameworks have made progress in increasing female representation in government, corporations, and non-profit sectors (Tuminez \& del Mar Garza, 2018). Given these statistics and pressures for more effective boards with greater female representation and women's economic empowerment in the region, a shift of perspective from a macro level gender-neutral efficiency to an enterprise level profit-maximisation efficiency is needed to rationalise female representation at board level. Delineating the differences between positive and negative firm-performance 
outcomes associated with the presence of women at board level, as well as underlying factors that are predictive of their successful participation, may critically determine the appropriate framework and regulations to promote female participation and leadership in the economy.

Whilst ethical and social reasons for having more women on boards are irrefutable as board diversity improves board independence as well as monitoring of management, thus increasing the overall market valuation (Ntim, 2013), the significance of firms' economic performance as a direct outcome of high board gender diversity is still not widely accepted. Some prior studies have proposed various mechanisms that imply a positive relation between gender diversity and firm performance (see for example Gul, Srinidhi, \& Ng 2011; Vera \& Martinez, 2010; Carter, D'Souza, Simkins \& Simpson, 2010; Mahadeo, Soobaroyen \& Hanuman, 2012). Laboratory studies of cultural diversity, including gender diversity, have argued that team diversity has a positive impact on performance because of unique cognitive attributes that members share to the team (Cox \& Blake, 1991; Hambrick, Cho \& Chen, 1996). Cognitive diversity among heterogeneous members nurtures innovation, problem solving, and creativity, and as a result leads to superior performance as compared to cognitively homogeneous teams (DiTomaso, Post \& Parks-Yancy, 2007). However, there have been arguments against the effects of team diversity as hypothesized by social identity and similarity attraction theories. According to proponents of these approaches, personal characteristics such as age, ethnicity, gender, and expertise can be easily classified and labelled by individual members and may exhibit many communication problems and a low level of identity. Diversity divides the group into two subcategories i.e. the in-group (majority) and out-group (minority) (Westphal \& Milton, 2000). Group members who differ from the majority tend to have lower group loyalty (Randoy et al., 2006), lower levels of psychological commitments and higher levels of turnover intent and absenteeism (Marimuthu \& Kolandaisamy, 2009), hence a heterogeneous team may be dysfunctional (Earley \& Mosakowski, 2000; Campbell \& Vera, 2008) and associated with negative team performance (Bøhren \& Strøm, 2006; Adams \& Ferreira, 2009).

The present study is motivated by the contrasting results of the association between gender diversity and firm performance. This study complements the existing research by analysing the effect of board gender diversity (BGD) on firm performance indicators by using a cross sectional data of 3,368 small and medium sized enterprises (SMEs) from four ASEAN countries. The firm-level data come from the World Bank Enterprise Survey (ES) that is especially designed to analyse firm performance and job creation issues faced by European and Central Asian countries. Four eligible countries from ASEAN (Indonesia, Malaysia, the Philippines, and Thailand) where recent data sets are available and where research on whether female board participation affects firm performance has rarely been undertaken are selected for investigation and comparison. In this study, we apply adequate control over three grouping measures of firm size, firm ownership structure, and industry nature which are assumed to have pertinent discriminating effects when analysing the nature of the relationship between BGD and firm performance variables. In fact, the random effects of each of these three intervening factors have been inadequately explored by previous studies in terms of explaining the differential outcomes between diverse and non-diverse female firm ownership; unless such different settings are accordingly controlled for, it is likely that the research would yield biased deductions of 
performance outcomes and lead to incongruous policy decisions. Business relative performance measures such as sales growth, sales to fixed assets ratio, sales per employee, cost of sales ratio and sales growth are selected as part of the diverse dependent variables in testing our model. These multiple dimension responses are specified to ensure that a broad spectrum of performance standards is included in the study.

\section{Literature Review}

Much of the literature on female board members is descriptive and does not distinctly develop a theoretical framework (Terjesen, Sealy \& Singh, 2009). The majority of the studies investigate why women are underrepresented on boards of companies. Notwithstanding this, two main theories have been frequently used to explain the impact of board members on a firm's performance (Johnson, Schnatterly \& Hill, 2013). Those theories are agency theory, which was formulated by Jensen and Meckling in 1976, and resource dependency theory, which was established by Pfeffer and Salancik in 1978. Even though these theories are not specifically developed to address the issue of board diversity, both provide constructive insights into the impact of BGD on firm performance.

\section{Agency Theory}

Agency theory is considered as the first and most widely used theoretical perspective in the field of corporate governance (Daily, Dalton, \& Canella, 2003). One of the critical issues in corporate governance is whether stockholder interests can be effectively protected or not. According to agency theory, stockholders (also called principals) delegate the control of a firm to the manager (also called agents). This approach, however, generates a potential risk in that agents may serve their own interests to the detriment of principals. Agency theory is particularly developed to understand and solve these potential opportunistic behaviors by managers (Williamson, 1975; Jensen \& Meckling, 1976).

In the context of agency theory, one of the most important roles of the board of directors is to monitor the self-serving behavior of managers, thereby reducing agency costs resulting from the separation of ownership and control (Carter et al., 2003). Even though agency theory does not provide an immediate prediction about the influence of board characteristics on firm performance (Carter et al., 2003; Smith et al., 2005), it describes added qualities brought in by female board members that enable to hypothesise about the impact of board gender diversity on firms' financial performances.

There are many empirical evidences that demonstrate female directors are generally better monitors who tend to hold management accountable for activities misalignment with firm interests (Farrel \& Hersch, 2005; Adams \& Ferreira, 2009; Triana, Miller \& Trzebiatowski, 2013; Dang, Bender \& Scotto, 2014). Having female directors on the board can reduce accounting manipulation and improve the informativity of the accounting numbers (Abdullah \& Ismail, 2016). They often bring new perspectives into complicated issues (Francoeur, Labelle \& Sinclair-Desgagne, 2008), as they tend to ask more questions (Carter et al., 2003), provide higher levels of board 
accountability and are better prepared for meetings (Adam \& Ferreira, 2009). Hence, any unforeseen informational bias in strategy formulation and decision-making processes can be minimised (Westphal \& Milton, 2000), in a way that also confines the agency risks of moral hazards and adverse selections (Lambert, 2001).

Other empirics of an agency view also hold that board independence is an important characteristic for the board to function in the best interests of the shareholders (Carter et al., 2003). Independent directors who have no material relationships with management or key shareholders are found to behave more independently than affiliated directors (Terjesen et al., 2009). Hence, they are expected to be more effective in monitoring management and lead to improved financial disclosure (Haniffa \& Cooke, 2002; Dey, 2008). In addition to improving monitoring management performance, the majority of independent structure has the advantage of providing supervision of information flows from the firm to outside stakeholders (Biondi et al., 2007) and representing shareholders' interests in major company decisions such as investments, takeovers, and CEO replacements (Del Guercio et al, 2003). Anderson et al. (2004) find that board independence is a better predictor of disclosure informativeness compared to audit committee independence.

\section{Resource Dependence Theory}

Another frequently used theory is the resource dependence theory, in which a firm is viewed as an open system that has an interdependent relationship with external entities and the general populace (Pfeffer \& Salancik, 1978). Organisations are conceived to succeed by minimizing their dependence on other organisations for the supply of important resources and firm directors per se play a key role in influencing the environment to make resources available. Their ability to use differences of power and strategies to different stakeholders in order to assert control over external resources also determines their merits to the organisation (Daily et al., 2003).

Within the setting of this theory, some findings show that female directors can bring unique qualities to the boards. They are relatively more socially adept than their male counterparts, and they can easily create linkages to external stakeholders such as customers, suppliers, or future employees and suppliers, and can even provide expert advice about the political groups and social initiatives in a community, and impact those powerful groups that could, in turn, impact the business (Hillman et al., 2007). They are also more effective than their male counterparts concerning diffusing knowledge, skills and experiences to their boards (Terjesen et al., 2009). The positive effects of the board gender diversity on firm financial performance is further supported by Brammer, Millington and Pavelin's (2007) study, which has found a positive reputational effect of female board of director members, serving a legitimising function, as described by Pfeffer and Salancik (1978) above. Certo, Daily, and Dalton (2001) find that more prestigious boards experienced better performance (less under-pricing) at their initial public offering. This suggests that female director appointments can enhance the credibility and performance of the firm; therefore, we assert the following:

H1 There is a positive relationship between BGD level and firm performance variables. 


\section{Organizational Determinants of Board Gender Diversity}

\section{Firm Size}

We now turn to the context specificity under which board gender diversity benefits may be of the greatest value. Empirical studies have shown that the benefits of board gender diversity are importantly and systematically determined by a variety of firm and industry characteristics that influence the relative costs and benefits of appointing female directors. Concerning firm size, it is argued that larger and more visible organisations experience more pressure to comply with societal expectation, including board gender diversity compliance (Dimaggio \& Powell, 1983). This perspective parallels Suchman's (1995) hypothesis that larger firms are more highly exposed to public scrutiny as they are more visible to the public and are more noteworthy. Hence, voluntary compliance can be explained as an effort to protect the firm against the adverse effects of regulations or body politics (Adams, Hill, \& Roberts, 1998; Clarke \& Gibson-Sweet, 1999). In line with that argument, we would expect that the larger the firms, the more likely they are to be politically visible and engage in legitimizing behaviour, including board gender diversity compliance. The following hypothesis captures these arguments:

H2 If firms are large (small), the relationship between BGD and one of the firm performance variables will be stronger (weaker).

\section{Ownership Structure}

The ownership structure of a firm is expected to have significant implications on the relationship between board gender diversity and firm financial performance. Firms with limited liability (dispersed ownership) are expected to have more accountability, transparency and disclosure as they are more visible and are held more accountable by the public at large than those firms with unlimited liability (concentrated ownership) (Samaha \& Dahawy, 2011). The separation of ownership and administration has strengthened dispersed ownership's influence over to the level of voluntary disclosure and public accountability (Morck, Wolfenzon \& Bernard, 2005). Voluntary disclosure and regulatory compliance by management might reduce the firm's cost of monitoring and regulation by the controlling shareholders. In contrast, firms with concentrated ownership structure are likely to be less transparent (Mohd Ghazali \& Weetman, 2006) than dispersed ownership due to various reasons. Khan and Vieito (2013) suggested that the greater ability and incentives of the controlling shareholders to control the behaviour of management in concentrated ownership have led to fewer issues in the principal-agency relationship, and hence there is less need for voluntary disclosure and fewer incentives to act in the best interests of the minority shareholders. The following hypothesis reflects these arguments:

H3 For firms with dispersed (concentrated) ownership structure, the relationship between BGD and one of the firm performance variables will be stronger (weaker). 


\section{Industry Nature}

The nature of an industry has been proposed as an influence on the benefit of female representation on boards of directors (Hillman et al., 2007). Some studies disclose correlations between particular industry sectors and board gender diversity (see for example Brammer et al., 2007; Fryxell \& Lerner, 1989; Hillman et al., 2007). Based on resource dependency theory, it is expected that more women directors will be found in industries with a larger female workforce (Hillman et al., 2007). As discussed above, the presence of women on a firm's board has a symbolic legitimising value both internally and externally. Where women hold executive directorships, firms are likely to gain legitimacy from female employees and be perceived by potential newcomers as equal opportunity employers that prohibit discrimination and promote career paths for both women and men (Sealy, Singh \& Vinnicombe, 2008). These various arguments imply the following hypothesis:

H4 For firms with greater (less) female employment bases, the relationship between BGD and one of the firm performance variables will be stronger (weaker).

\section{Research Method}

\section{Sample}

The study uses a selected sample of countries and standardized survey questionnaires from the World Bank's Enterprise Surveys to examine the hypotheses described above. Our sample includes cross sectional data from 3,368 manufacturing firms in 4 ASEAN countries (Indonesia, Malaysia, the Philippines, and Thailand). These four ASEAN countries are chosen in order to reduce the amount of missing data particularly for key variables of BGD and sales variable. In order to provide uniformity and enhance comparability, we focus on surveys conducted concurrently in these four countries in 2015.

The data cover formal firms that are classified with ISIC codes 15-37, 45, 50-52, 55, 60- 64, and 72. Interviewers conduct face-to-face interviews using standardized questionnaires for the manufacturing and service sectors. Topics covered include information on firm characteristics, the business environment, access to finance, annual sales, costs of inputs and labor, workforce composition, and basic performance measures. Sample data is then stratified using random sampling with replacement along strata for firm size, firm ownership structure, and industry nature. Detail definition of industry classification from ES survey is presented in Table 1. 
Table 1: Industry Classifications

\begin{tabular}{|c|c|c|}
\hline \multirow{2}{*}{$\begin{array}{l}\text { Industries } \\
\text { Manufacturing }\end{array}$} & \multicolumn{2}{|c|}{ Two-digit Codes (ISIC Rev.3.1) } \\
\hline & 15 & Food \\
\hline & 16 & Tobacco \\
\hline & 17 & Textiles \\
\hline & 18 & Garments \\
\hline & 19 & Leather \\
\hline & 20 & Wood \\
\hline & 21 & Paper \\
\hline & 22 & Publishing and Recorded media \\
\hline & 23 & Refined Petroleum \\
\hline & 24 & Chemicals \\
\hline & 25 & Plastic and rubber \\
\hline & 26 & Non-metallic mineral products \\
\hline & 27 & Basic metals \\
\hline & 28 & Fabricated metal products \\
\hline & 29 & Machinery, equipment $(29 \& 30)$ \\
\hline & 31 & Electronics $(31 \& 32)$ \\
\hline & 33 & Precision instruments \\
\hline & 34 & Transport machines (34 \&35) \\
\hline & 36 & Furniture \\
\hline & 37 & Recycling \\
\hline Retail and & 52 & Retail \\
\hline Other Services & 51 & Wholesale \\
\hline & 72 & IT \\
\hline & 55 & Hotel and Restaurants \\
\hline & 50 & Services of motor vehicles \\
\hline & 45 & Construction \\
\hline & 60 & Transport (60-64) \\
\hline
\end{tabular}

Source: World Bank Enterprise Survey, Manufacturing Module (2015)

The data includes firms from all industry classifications. We exclude firms in which the government holds at least 50 per cent of shares. Finally, we drop observations with missing or negative values for sales and costs. To allow for the possibilities of transient fluctuations in the real exchange rates of the various countries against the US Dollar, we convert local currency values in the year of the survey into US dollars valued at the 2015 rate.

Based on respondents' responses to the survey instrument, there are considerable differences in diversity levels among countries in the sample. The variation in the variable indicates that there might be specific qualities, constraints and opportunities affecting the diversity level in the context of each country's environment. Figure 1 shows that the occurrence of BGD is highest in Thailand and the lowest in Indonesia. About 50 per cent of firms operating in the Philippines and Thailand exercise an inclusive policy with women having at least 1 per cent of the firm ownership. 
Figure 1: Percentage of BGD by Countries (\%)

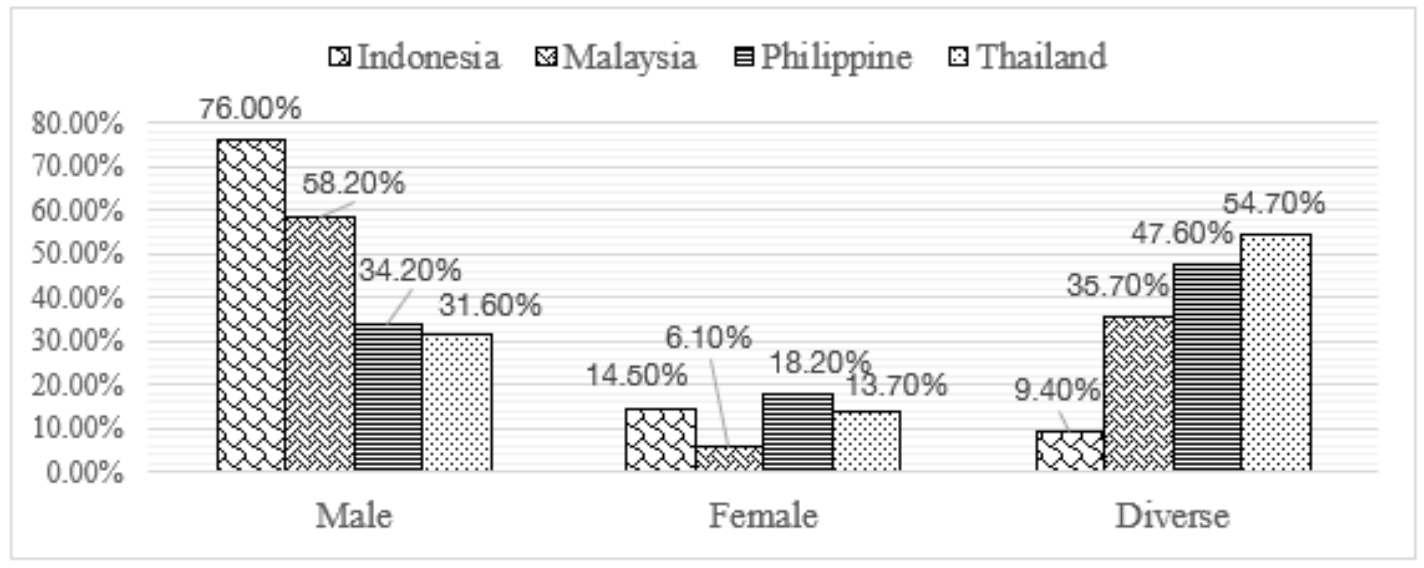

Source: Derived from survey data

BGD also varies by sector (see Figure 2). The highest percentage of BGD is exerted by transport (64: 75\%), transport machines (34: 53.3\%), IT (72: 46.7\%), paper (21: $45 \%$ ) and electronics (31: 43.5\%) sectors. About 40 to 100 per cent of firms operating in these five sectors have more board gender diversity as compared to other sectors. Conversely, a large proportion of firms in sectors such as refined petroleum products (23: 80\%), non-metallic mineral products (26: 79.4\%), basic metals $(27: 75.9 \%)$, and precision instruments $(33: 77.8 \%)$ are still strongly led by male rather than diverse boards of directors. All-male boards of directors control all firms sampled in the machinery and equipment (30: 100\%) sector for instance. One particular sector in which all sampled firms are run by female boards of directors is the transport sector (62: 100\%). Despite these differences indicating that each sector has certain internal characteristics and external circumstances represented in the country in which each firm operates, the variation between all-male and diverse groups in Figure 2 underscores the necessity for the organisation and industry as a whole to embrace the value of diversity, which will fuel a conducive environment for female groups to assume leadership roles.

Figure 2: Average BGD by Sector (\%)

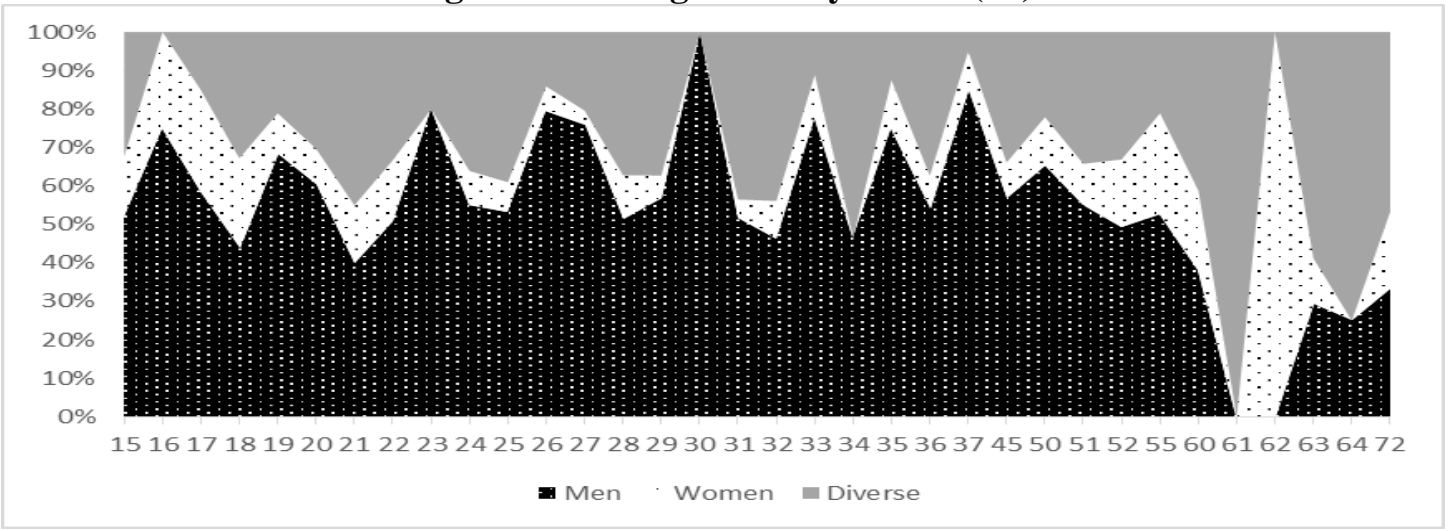

Source: Derived from survey data 


\section{Measures}

In this paper, a method for measuring BGD is to use two indicators from the questionnaire. The first indicator is by asking the firm whether some of the owners of the firm are female. The second indicator is by asking what percentage of the firm is owned by females. Low percentages of BGD practices exercised by about 60 per cent of all sectors in these countries (see Figure 2) may suggest low awareness and acceptance of various dimensions of workplace diversity, and as a result companies might be at the low level of firm performance, as it is normally hypothesized that these two measures pose a positive relationship. This assumption, however, may not be fully answered unless testings are undertaken and if the assumption is valid, then firms that are not adopting BGD are expected to report lower firm productivity performance than those that have both men and women in their boards of directors. The degree of association between BGD and firm performance is also expected to increase as the firm's size increases, the ownership structure becomes more dispersed, and the firm's female employment base becomes larger. Table 2 provides a full description of the variables employed in the empirical analysis.

Table 2: Variable Definitions

\begin{tabular}{|c|c|c|}
\hline Variable & Definitions & Measurement \\
\hline Board Gender Diversity & $\begin{array}{l}\text { The percentage of firm ownership } \\
\text { as to whether it is owned by male } \\
\text { or female or by gender-diverse. }\end{array}$ & Continuous. \\
\hline Firm Size & Permanent, full-time employees. & Continuous. \\
\hline Sales Growth & $\begin{array}{l}\text { Sales growth rate from } 2012 \text { to } \\
2015\end{array}$ & Continuous. \\
\hline $\begin{array}{l}\text { Earnings Before Interest } \\
\text { and Tax }\end{array}$ & $\begin{array}{l}\text { The ratio of total expenses to the } \\
\text { sales revenue. }\end{array}$ & Continuous. \\
\hline Firm Level Employment & Permanent, full-time employees. & Continuous. \\
\hline Ownership Structure & Firm's legal status. & $\begin{array}{l}\text { Ordinal: } \\
1 \text { = sole proprietorship; } \\
2 \text { = partnership; } \\
3 \text { = limited partnership; } \\
4 \text { = shareholding company } \\
\text { with non-traded shares or } \\
\text { shares traded privately; } \\
5=\text { shareholding company } \\
\text { with shares traded in the stock } \\
\text { market. }\end{array}$ \\
\hline Industry Nature & $\begin{array}{l}\text { Permanent, full-time female } \\
\text { employees. }\end{array}$ & Continuous. \\
\hline
\end{tabular}

Source: Derived from survey data

Based on the concepts used in the hypotheses, we include firm size, ownership structure, and firms' female employment bases as organizational variables expected to mediate the relationship between BGD and firm performance. The firm's exposure and vulnerability to public scrutiny, which is common for larger-sized firms, have been strongly related to board gender diversity adoption and practices (Suchman, 1995). It is assumed that the more the real assets firm have, the greater the firm's commitment to gender diverse compliance compared to smaller firms. Furthermore, 
firms with limited liability (diffused ownership) have more development attributes than those firms with unlimited liability (concentrated ownership).

Additionally, board gender diversity are also driven by the nature of the industry that can vary due mostly to differences in structure, conduct, and performance of each industry player. When female directors on board are more visible, the firm's perceived legal compliance as an equal opportunity employer becomes more plausible in any employment and hiring options (Sealy et al., 2008).

Given the nature of secondary data used in this research, we measured firm performance variables using all those items provided by the source. There are three items related to firm performance that we can use from this source, and they are: 1) sales growth; 2) fixed-asset turnover ratio; 3) cost to sales revenue ratio; 4) sales per employee ratio (Capon, Farley \& Hoenig, 1996). The measure of sales growth in this study indicates whether the average sales volume of a company's products or services has expanded or contracted in the last four years. The measure of the fixed-asset turnover ratio reflects the ability of a firm to generate net sales from fixed asset investments. Greater ability confirms improved performance, and so such ratios are likely to be of interest to investors who wish to see returns maximized. The cost to sales revenue ratio shows the level of resources required to generate every dollar of sales revenue (costs/sales revenue) and tells us more about the efficiency and productivity of company's operations. Sales per employee ratio suggest how efficient a firm is in utilizing its employee (see Table 2). The relationship between GDB and firm performance is conceptualized as a two-stage relationship where a causal factor impact on a series of intermediate indicators, which in turn determine the final outcome in terms of changes in firm performance indicators (see Figure 3).

Figure 3: Conceptual Framework of the Study

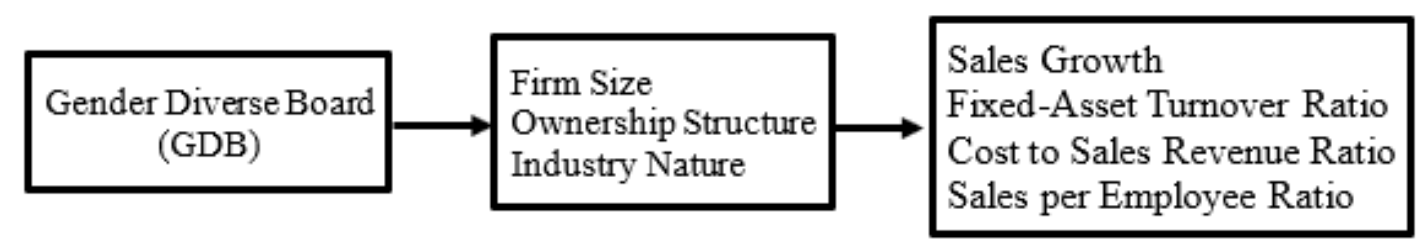

\section{Results}

In Figure 4, we present structural equation model analyses for all dependent firm performance variables (sales growth, fixed-asset turnover ratio, cost to sales revenue ratio, and sales per employee) with BGD level as an independent variable and each controlling variable (firm size, ownership structure, and industry nature) that can be used to support respective hypothesis. Figure 3 displays the saturated model for all possible paths and correlations. The model and the data, has been bootstrapped in our analysis, indicate a very good fit in which the discrepancy divided by the degrees of freedom is not significant and stand at 2.183 (p-value $=0.088$ ). Several fit measures such as NFI, RFI, IFI, TLI, and CFI values are all close to 1 indicating a model fit of the data $(.996,963, .998, .979$ and .998 respectively) (McDonald \& Marsh, 1990). 
RMSEA of 0.049 which is less than 0.05 indicates a close fit between the model and the data (Browne \& Cudeck, 1993).

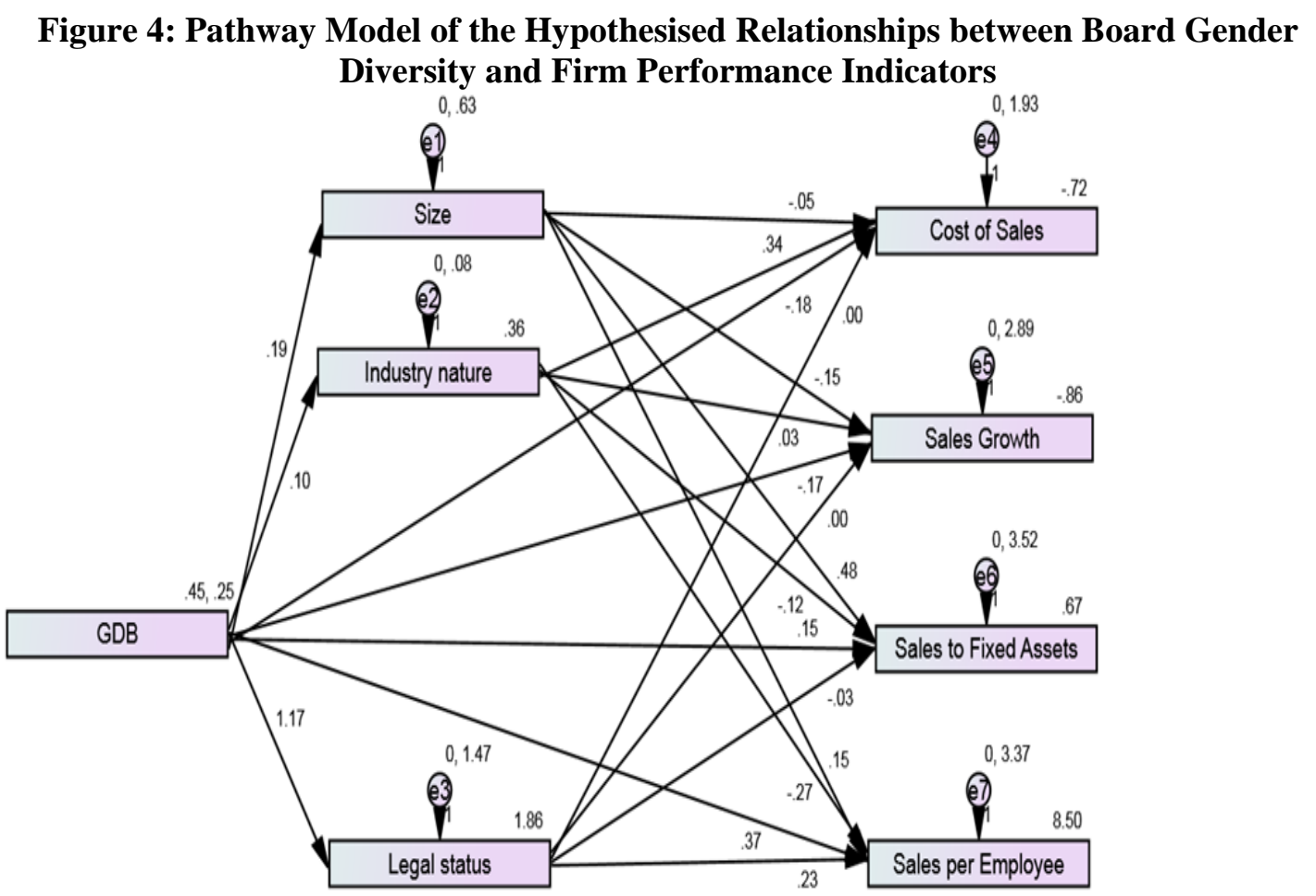

The R column of Table 3 provides the implied correlation results to find out whether BGD and each of four firm performance variables had relationships that could be used to provide plausible evidence to support hypotheses 1. Following the results, correlation coefficients revealed an unexpectedly significant negative correlation between BGD level and sales growth, at 1 per cent significance level ( $r=0.079$ and $p-$ value $=0.000$ ). BGD level is also significantly and negatively correlated with the cost to sales revenue ratio, at 1 per cent significance level $(r=0.059$ and $p$-value $=0.000)$. The relationship became positive when BGD level is paired with each sale to fixed asset ratio $(r=0.060$ and $p$-value $=0.002)$ and sales per employee ratio $(r=0.170$ and p-value $=0.000$ ), proposing that increasing levels of BGD are associated with increasing firm performance, which provided partial support for Hypothesis 1.

Table 3: Implied Correlations for All Variables (Default Model)

\begin{tabular}{|l|c|c|c|c|c|c|}
\hline & \multicolumn{3}{|c|}{$\begin{array}{c}\text { Unstandardized } \\
\text { Coefficients }\end{array}$} & $\begin{array}{c}\text { Standardized } \\
\text { Coefficients }\end{array}$ & & \\
\hline Path & R & B & S.E. & Beta & t & Sig. \\
\hline BGD > Size & 0.120 & 0.192 & 0.027 & 0.120 & 7.040 & $* * *$ \\
\hline BGD > Industry nature & 0.175 & 0.096 & 0.009 & 0.174 & 10.274 & $* * *$ \\
\hline BGD > Legal status & 0.439 & 1.173 & 0.041 & 0.439 & 28.315 & $* * *$ \\
\hline BGD > Cost to sales revenue & -0.059 & -0.175 & 0.054 & -0.063 & -3.249 & $* * *$ \\
\hline BGD > Sales growth & -0.079 & -0.168 & 0.066 & -0.049 & -2.541 & $* *$ \\
\hline BGD > Fixed-assets turnover & 0.060 & 0.148 & 0.073 & 0.039 & 2.035 & $*$ \\
\hline BGD > Sales per employee & 0.170 & 0.369 & 0.071 & 0.098 & 5.186 & $* * *$ \\
\hline Size > Cost to sales revenue & -0.031 & -0.045 & 0.030 & -0.026 & -1.506 & NS \\
\hline Size > Sales growth & -0.107 & -0.154 & 0.037 & -0.072 & -4.188 & $* * *$ \\
\hline
\end{tabular}




\begin{tabular}{|l|c|c|c|c|c|c|}
\hline Size > Fixed-assets turnover & 0.253 & 0.476 & 0.041 & 0.199 & 11.736 & $* * *$ \\
\hline Size > Sales per employee & 0.085 & 0.153 & 0.040 & 0.065 & 3.858 & $* * *$ \\
\hline $\begin{array}{l}\text { Industry nature > Cost to sales } \\
\text { revenue }\end{array}$ & 0.057 & 0.339 & 0.087 & 0.068 & 3.883 & $* * *$ \\
\hline Industry nature > Sales growth & -0.006 & 0.032 & 0.107 & 0.005 & 0.303 & $\mathrm{NS}$ \\
\hline $\begin{array}{l}\text { Industry nature > Fixed-assets } \\
\text { turnover }\end{array}$ & -0.006 & -0.121 & 0.118 & -0.018 & -1.024 & $\mathrm{NS}$ \\
\hline $\begin{array}{l}\text { Industry nature > Sales per } \\
\text { employee }\end{array}$ & -0.010 & -0.274 & 0.115 & -0.040 & -2.372 & $* *$ \\
\hline $\begin{array}{l}\text { Legal status > Cost to sales } \\
\text { revenue }\end{array}$ & -0.029 & 0.000 & 0.020 & 0.000 & -0.121 & $\mathrm{NS}$ \\
\hline Legal status > Sales growth & -0.037 & 0.001 & 0.024 & 0.001 & 0.058 & $\mathrm{NS}$ \\
\hline $\begin{array}{l}\text { Legal status > Fixed-assets } \\
\text { turnover }\end{array}$ & 0.009 & -0.025 & 0.027 & -0.018 & -0.948 & $\mathrm{NS}$ \\
\hline $\begin{array}{l}\text { Legal status > Sales per } \\
\text { employee }\end{array}$ & 0.205 & 0.226 & 0.026 & 0.161 & 8.650 & $* * *$ \\
\hline
\end{tabular}

$* * *, * *, *$, NS denotes significance at $1 \%, 5 \%, 10 \%$ levels and insignificant respectively (2-tailed)

The outstanding hypotheses are tested by determining the statistical significance of the path coefficients. To evaluate the estimated causal relations, the actual size of each parameter is assessed regarding the standardised $\beta$ coefficients and $\rho$-values. Table 3 presents the regression weights for BGD variable in predicting sales growth, fixedassets turnover ratio, sales per employee, and cost to sales revenue ratio while controlling for size, ownership structure, and industry nature.

The results establish that the relationships between BGD as an independent variable, size, industry nature, and legal status as intervening variables, and each of the firm performance variables are weakly to moderately linear. The sample correlations range from a low of 0.006 to a high of 0.439 . The regression weights that are found to be significantly different from zero at the 0.05 level in the direct prediction of cost to sales revenue ratio are BGD and industry nature. Variables that are significantly different from zero at the 0.05 level in predicting sales growth and fixed-assets turnover ratio are BGD and size. BGD, size, industry nature and legal status are all significant in the direct prediction of sales per employee variable.

Since these significant paths partially satisfy the conditions of mediational testing of having significance in three separate paths, they are subject to further mediation test. The results from the two-tailed significance of bias-corrected percentile method indicate that Size fully and significantly mediates BGD and three performance measures of Sales growth, Fixed-assets turnover ratio, and Sales per employee ratio. Industry nature also fully and significantly mediates the relationship between BGD and two performance measures of cost to sales revenue and Sales per employee ratios. Legal-status is a full and significant mediator between BGD and Sales per employee. 
Table 4: Mediation Test

\begin{tabular}{|l|c|c|c|}
\hline Relationship & $\begin{array}{c}\text { Direct Without } \\
\text { Mediator }\end{array}$ & $\begin{array}{c}\text { Direct With } \\
\text { Mediator }\end{array}$ & Indirect \\
\hline BGD Size Sales growth & $-0.057(0.000)$ & $-0.049(0.004)$ & Sig. Med $(0.009)$ \\
\hline BGD Size Fixed-assets turnover & $0.052(0.002)$ & $0.039(0.022)$ & Sig. Med $(0.011)$ \\
\hline BGD Size Sales per employee & $0.169(0.000)$ & $0.099(0.000)$ & Sig. Med $(0.007)$ \\
\hline BGD Industry nature Cost to sales revenue & $-0.055(0.001)$ & $-0.063(0.000)$ & Sig. Med $(0.005)$ \\
\hline BGD Industry nature Sales per employee & $0.169(0.000)$ & $0.099(0.000)$ & Sig. Med $(0.008)$ \\
\hline BGD Legal status Sales per employee & $0.169(0.000)$ & $0.098(0.000)$ & Sig Med $(0.008)$ \\
\hline
\end{tabular}

As indicated in Table 4, we find positive and significant relationships between BGD and fixed-assets turnover ratio as well as between BGD and Sales per employee when controlling for the size variable. We also find positive and significant association between BGD level and sales per employee when controlling for each of industry nature and legal status separately, all of which provide sufficient evidence to support hypotheses two, three and four at 5 per cent significance level. It is interesting to note that when we combine multiple mediating variables simultaneously, BGD only positively and significantly affects sales per employee.

\section{Discussion}

We analyzed a sample of 3,368 firms to test the mediating functions of size, industry nature, and legal status in the relationship between the board gender diversity and business performance. The basis of our hypotheses is drawn out of agency and resource dependency theories. Results in ASEAN context encourage the value in board gender diversity by demonstrating that board gender variety is positively associated with two efficiency indicators of fixed asset ratio and sales per employee ratio. We also find support for mediators between BGD and these two performance indicators. These findings suggest that businesses might anyhow benefit from diverse societal and human capital. This gives partial support for the respective theories because having women on a board is reasonably related to positive firm performance (Dang et al., 2014; Terjesen et al., 2009; Hillman et al., 2007; Brammer et al., 2007).

We identified that size fully and significantly mediates the relationship between BGD and two indicators of fixed-assets turnover and sales per employee, but becomes significantly negative when we connect BGD and sales growth through size. In other words, that hypothesis received mixed results. This finding, however, is in contrast with resource dependence principle which predicts that larger size firms with board gender diversity may increase business values by efficiently resorting to its resources and capabilities to generate revenues. The positive fixed asset turnover computations suggest that as firms become larger, their use of fixed assets to generate sales become more efficient. On a separate test, we discovered that industry nature fully and significantly mediates the relationship between BGD and sales per employee and cost to sales revenue. However, the test also obtained mixed results. It is positively affecting sales per employee, while negatively affecting the cost to sales revenue ratio. The negative effect in this test, to some extent, contradicts the agency theoretical perspective, possibly because the diversity effect has a point of diminishing returns or "critical mass" (Torchia et al., 2011). This is when the additional firm's effectiveness to control expenses from more board gender diversity 
decreases as diversity increases (Ali, Kulik \& Metz, 2011; Nakagawa \& Schreiber, 2014). Nonetheless, this newly arising assumption is subject to further analysis to attest to some previous empirical examinations that find conflicting diversity findings and offer direction for ongoing research in this field. Specifically, since the data set corresponds to a single year's contents and is secondary in nature, future studies should examine the pattern of relationship when the data set comprises activities during a given period of time and or use primary sources that include natural performance measures. By blending differences and dynamics of historical records and or using natural way to measure the objective achievement, we can capture more accurate inference of model parameters.

Legal status as a mediating variable is also found to be significant when we discretely connected BGD and sales per employee. Sales per employee metric is thought of as the least preferable method for appraising business performance. Its simplicity, however, can reveal a firm's sales-generating capability and trends more than gross sales. The ratio gives insight into relative productivity or projected growth rates that is additionally actionable in and around itself as compared to gross sales (Gildersleeve, 1999). The positive result in this separate test implies that with increased diffusion of liability, the relative monitoring and regulation cost-advantage may stimulate firms to engage more in efficiency initiatives, while very large and concentrated liability has less incentive to further increase efficiency exposure (Morck et al., 2005).

Furthermore, our analysis finds an interesting interaction effect between BGD and sales per employee when controlling for all three mediating variables. The result from this pooled test discloses that firms with more women on their boards, larger sizes, and more diffused structure might achieve additional benefits through sales generating capabilities and trends. Higher sales per employee trends are often the sufficient indicator of either meeting sales targets or improving employee productivity. Many factors combine to influence the level of employee productivity. Increased morale, incentive, education, expertise, teamwork and the use of computerised tools to perform the work more efficiently, all contribute to high productivity (Bynum, 2005). Increases in sales per employee, however, are not the result of excessive overtime, which could lead to exhaustion and decreasing morale. This study's results suggest that the connection between management group demography and the organisational outcome may be more complicated than researchers have previously uncovered. As hypothesised, a positive association is found between the BGD and performance. The positive implications of BGD such as prudence, self-regulation, curiosity, creativity and multiple perspectives seem to promote and uplift firms' productivity and efficiency in the markets. This particular result supports and extends previous diversity research that find a similar association between BGD and firm performance (Brammer et al., 2007; Certo et al., 2001; Dang et al., 2014).

\section{Implications for Asian Business Context}

This paper has important implications for practice. ASEAN countries have approved an action agenda on Mainstreaming Women's Economic Empowerment (WEE) during the 31st Association of Southeast Asian Nations Summit. While this agreed policy might positively affect women's role in the workforce and provide avenues towards achieving a non-discriminatory and equal-opportunity working environment, 
the decision makers need to be well-informed of the empirical evidence that suggests that the inclusive policy will initially improve but then possibly decrease the financial performance of these companies. The results demonstrate BGD's impact on firm performance is subject to the organisational context in which it exists. The findings suggest that BGD should enhance performance for firms seeking to improve efficiency and productivity.

\section{References}

Abdullah, S. N., \& Ismail, K. N. I. K., (2016), "Women directors, family ownership and earnings management in Malaysia", Asian Review of Accounting, vol. 24, no. 4, pp. 525-550.

Anderson, R., Mansi, S., \& Reeb, D., (2004), "Board characteristics, accounting report integrity, and the cost of debt", Journal of Accounting and Economics, vol. 37, no. 3, pp. 315-342.

Adams, C. A., Hill, W. Y., \& Roberts, C. B., (1998), "Corporate social reporting practices in Western Europe: Legitimating corporate behaviour", The British Accounting Review, vol. 30, no. 1, pp. 1-21.

Adams, R. B., \& Ferreira, D., (2009), "Women in the boardroom and their impact on governance and performance", Journal of Financial Economics, vol. 94, no. 2, pp. 291309.

Ali, M., Kulik, C. T., \& Metz, I., (2009), "The impact of gender diversity on performance in services and manufacturing organizations", Academy of Management Best Papers Proceedings, pp. 1-6.

Biondi, Y., Canziani, A., \& Kirat, T. H., (2007), The firms as an entity: Implications for economics, accounting and the law, Routledge, London.

Bøhren, Ø., \& Strøm, R. Ø., (2010), "Governance and politics: Regulating independence and diversity in the board room", Journal of Business Finance and Accounting, vol. 37, no. 9-10, pp. 1281-1308.

Brammer, S., Millington, A., \& Pavelin, S., (2007), "Gender and ethnic diversity among UK corporate boards", Corporate Governance: An International Review, vol. 15, no. 2, pp. 393-403.

Bynum, J. W., (2005), Quality: A total management concept, a philosophical approach, AuthorHouse, Indiana.

Campbell, K., \& Mínguez-Vera, A., (2008), "Gender diversity in the boardroom and firm financial performance", Journal of Business Ethics, vol. 83, no. 3, pp. 435-451.

Carter, D. A., Simkins, B. J., \& Simpson, W. G., (2003), "Corporate governance, board diversity, and firm value", Financial Review, vol. 38, no. 1, pp. 33-53.

Carter, D. A., D'Souza, F., Simkins, B. J., \& Simpson, W. G., (2010), "The gender and ethnic diversity of US boards and board committees and firm financial performance", Corporate Governance: An International Review, vol. 18, no. 5, pp. 396-414.

Certo, T., Daily, C., \& Dalton, D., (2001), "Signalling Firm value through board structure: An Investigation of initial public offerings", Entrepreneurship Theory and Practice, vol. 26, no. 2, pp. 33-50.

Chotiyaputta, V., \& Yoon, Y., (2018), "Women on the board and firm performance of Thai publicly listed companies in the SET100, 2008-2017, PSAKU", International Journal of Interdisciplinary Research, vol. 7, no. 1, pp. 149-160.

Clarke, J., \& Gibson-Sweet, M., (1999), "The use of corporate social disclosures in the management of reputation and legitimacy: A cross-sectoral analysis of UK Top 100 companies business ethics", European Review, vol. 8, no. 1, pp. 5-13.

Cox, T., \& Blake, S., (1991), "Managing cultural diversity: Implications for organisational competitiveness", Academy of Management Executive, vol. 5, no. 3, pp. 45-56. 
Daily, C. M., Dalton, D. R., \& Cannella, A. A., (2003), "Corporate governance: Decades of dialogue and data", Academy of Management Review, vol. 28, no. 3, pp. 371-382.

Dang, R., Bender, A. F., \& Scotto M. J., (2014), "Women on French corporate board of directors: How do they differ from their male counterparts?", Journal of Applied Business Research, vol. 30, no. 2, pp. 489-508.

Dey, A., (2008), "Corporate governance and agency conflicts", Journal of Accounting Research, vol. 46, no. 5, pp. 1143-1181.

DiMaggio, P. J., \& Powell, W. W., (1983), "The iron cage revisited: Institutional isomorphism and collective rationality in organizational fields", American Sociological Review, vol. 48, no. 2, pp. 147-160.

Del Guereio, D., Dann, L. Y., \& Partch, M. M., (2003), "Governance and boards of directors in closed-end investment companies", Journal of Financial Economics, vol. 69, no. 1, pp. 111-152.

DiTomaso, N., Post, C., \& Parks-Yancy, R., (2007), "Workforce diversity and inequality: Power, status, and numbers", Annual Review of Sociology, vol. 33, no. 1, pp. 473-501.

Farrel, K. A., \& Hersch, P. L., (2005), "Additions to corporate boards: The effect of gender", Journal of Corporate Governance, vol. 11, no. 1-2, pp. 85-106.

Francoeur, C., Labelle, R., \& Sinclair-Desgagne, B., (2008), "Gender diversity in corporate governance and top management", Journal of Business Ethics, vol. 81, no. 1, pp. 83-95.

Fryxell, G. E., \& Lerner, L. D., (1989), "Contrasting corporate profiles: Women and minority representation in top management positions", Journal of Business Ethics, vol. 8, no. 5, pp. 341-352.

Gildersleeve, R., (1999), Winning business: How to Use financial analysis and benchmarks to outscore your competition, Gulf Publishing Company, Texas.

Gul, F. A., Srinidhi, B., \& Ng, A. C., (2011), "Does board gender diversity improve the informativeness of stock prices?", Journal of Accounting and Economics, vol. 51, no. 3, pp. 314-338.

Haniffa, R., \& Cooke, T. E., (2002), "Culture, corporate governance and disclosure in Malaysian corporations", Abacus, vol. 38, no. 3, pp. 317-349.

Hambrick, D. C., Cho, T. S., \& Chen, M. J., (1996), "The influence of top management team heterogeneity on firms' competitive moves", Administrative Science Quarterly, vol. 41, no. 4 , pp. 659-684.

Hillman, A. J., Shropshire, C., \& Cannella, A. A., (2007), "Organisational predictors of women on corporate boards", Academy of Management Journal, vol. 50, no. 4, pp. 941952.

ILO, (2017), "Women on boards: Building the female talent pipeline", Retrieved from http://www.ilo.org/wcmsp5/groups/public/---dgreports/-gender/documents/briefingnote/ wcms_410200.pdf

Jensen, M. C., \& Meckling, W. H., (1976), "Theory of the firm: Managerial behaviour, agency costs and ownership structure", Journal of Financial Economics, vol. 3, no. 4, pp. 305-360.

Johnson, S. G., Schnatterly, K., \& Hill, A. D., (2013), "Board composition beyond independence: Social capital, human capital, and demographics", Journal of Management, vol. 39, no. 1, pp. 232- 262.

Lambert, R. A., (2001), "Contracting theory and accounting", Journal of Accounting and Economics, vol. 32, no. 1, pp. 3-87.

Mahadeo, J. D., Soobaroyen, T., \& Hanuman, V. O., (2012), "Board composition and financial performance: Uncovering the effects of diversity in an emerging economy", Journal of Business Ethics, vol. 105, no. 3, pp. 375-388.

Mohd Ghazali N. A., \& Weetman, P., (2006), "Perpetuating traditional influences: Voluntary disclosure in Malaysia following the economic crisis", Journal of International Accounting, Auditing and Taxation, vol. 15, no. 2, pp. 226-248.

Morck, R., Wolfenzon, D., \& Bernard, Y., (2005), "Corporate governance, economic entrenchment, and growth", Journal of Economic Literature, vol. 43, no. 3, pp. 655720. 
Nakagawa, Y., \& Schreiber, G. M., (2014), "Women as drivers of Japanese firms' success: The effect of women managers and gender diversity on firm performance", Journal of Diversity Management, vol. 9, no. 1, pp. 1-21.

Ntim, C. G., (2013), "Corporate governance, affirmative action and firm value in postapartheid South Africa: A simultaneous equation approach", African Development Review, vol. 25, no. 2, pp. 148-172.

Pfeffer, J., \& Salancik, G. R., (1978), The external control of organizations: A resource dependence perspective, Harper and Row, New York.

Ramly, Z., Chan, S., Mustapha, M. Z., \& Sapiei, N. S., (2015), "Women on boards and bank efficiency in ASEAN-5: The moderating role of the independent directors", Review of Managerial Science, vol. 11, no. 1, pp. 225-250.

Samaha, K., \& Dahawy, K., (2011), "An empirical analysis of corporate governance structures and voluntary corporate disclosure in volatile capital markets: The Egyptian experience", International Journal of Accounting, Auditing and Performance Evaluation, vol. 7, no. 1/2, pp. 61-93.

Sealy, R., Singh, V., \& Vinnicombe, S., (2008), The female FTSE report 2008, Cranfield University, Cranfield.

Smith, N., Smith, V., \& Verner, M., (2005), "Do women in top management affect firm performance? A panel study of 2500 Danish firms, Discussion Paper August", Institute for the Study of Labour.

Suchman, M. C., (1995), "Managing legitimacy: Strategic and institutional approaches", Academy of Management Review, vol. 20, no. 3, pp. 571-610.

Terjesen, S., Sealy, R., \& Singh, V., (2009), "Women directors on corporate boards: A review and research agenda", Corporate Governance: An International Review, vol. 17, no. 3, pp. 320-337.

Torchia, M., Calabro, A., \& Huse, M., (2011), "Women directors on corporate boards: From tokenism to critical mass", Journal of Business Ethics, vol. 102, no. 2, pp. 299-317.

Triana, M. C., Miller, T. L., \& Trzebiatowski T. M., (2013), "The double-edged nature of board gender diversity: Diversity, firm performance, and the power of women directors as predictors of strategic change", Organization Science, vol. 25, no. 2, pp. 609-632.

Tuminez, A. S., \& del Mar Garza, M., (2014), "Women leaders and the new Asian century: Insights from the government, private sector, and civil society", Retrieved from https://lkyspp.nus.edu.sg/docs/default-source/gia-documents/women-leaders-and-thenew-asian-century_final.pdf?sfvrsn=f5796a0a_2

Vera, A. M., \& Martinez, R. L., (2010), "Female directors and SMEs: An empirical analysis", Journal of Global Strategic Management, vol. 8, pp. 34-46.

Westphal, J. D., \& Milton, L. P., (2000), "How experience and network ties affect the influence of demographic minorities on corporate board", Administrative Science Quarterly, vol. 45, no. 2, pp. 366-417.

Williamson, O. E., (1975), Markets and hierarchies: Analysis and antitrust implications, The Free Press, New York.

World Bank, (2018), "Labour force participation rate, female (\% of female population ages", Retrieved from https://data.worldbank.org/indicator/SL.TLF.CACT.FE.ZS 